\title{
Accounting earnings response coefficient: an extension to banking shares in Asia Pacific countries
}

\begin{abstract}
This paper reports new finding on earnings response coefficients for banking firms on how disclosures on total earnings and disaggregated fee earnings are used by investors to change share prices prior to earnings disclosures. The information relating to total earnings influences share prices significantly in all four banking sectors studied, all of which have sufficiently liberalized capital markets. Australian investors appear to use information on disaggregated non-interest fee income to revise share prices significantly: not so in other markets. The investors in Malaysia and South Korea appear to consider changes in fee income as bad news with negative price impact, anomalous to theory. The Australian investors appear to regard both total and fee incomes as equally important whereas investors in other markets either ignore or consider changes in fee income as bad news for share valuation. This study extends the literature on this topic from non-bank to banking firms.
\end{abstract}

Keyword: Value relevance; Earnings response coefficient; Interest and non-interest incomes; Unexpected earnings; Bank share prices; Asia Pacific region 